\title{
DISTRIBUTION OF PROTEIN I AND REGULATION OF ITS STATE OF PHOSPHORYLATION IN THE RABBIT SUPERIOR CERVICAL GANGLION $^{1}$
}

\author{
ERIC J. NESTLER AND PAUL GREENGARD ${ }^{2}$ \\ Department of Pharmacology, Yale University School of Medicine, New Haven, Connecticut 06510
}

Received December 28, 1981; Revised March 15, 1982; Accepted March 22, 1982

\begin{abstract}
The distribution and regulation of the state of phosphorylation of Protein I have been studied in the rabbit superior cervical sympathetic ganglion. The data indicate that the ganglion contains two pools of Protein I: a presynaptic pool that represents $60 \%$ of the total ganglion Protein I and a postsynaptic pool that represents $40 \%$ of the total ganglion Protein I. The state of phosphorylation of presynaptic Protein I, but not that of postsynaptic Protein I, is regulated by nerve impulse conduction, by dopamine, and by a high $\mathrm{K}^{+}$concentration. Studies of the excracellular calcium requirements for Protein I phosphorylation, as well as peptide-mapping analyses of Protein I, suggest that the effects of nerve impulse conduction and of a high $\mathrm{K}^{+}$concentration are mediated through the activation of calcium-dependent protein kinases and that the effect of dopamine is mediated through the activation of cyclic AMP-dependent protein kinase. The total amount of postsynaptic Protein I, but not that of presynaptic Protein I, is decreased by short periods of exposure to cycloheximide, a protein synthesis inhibitor. It is proposed that Protein I located in presynaptic nerve terminals plays a functional role in those terminals and that the Protein I located in cell bodies is newly synthesized and en route to nerve terminals.
\end{abstract}

Increasing evidence suggests that protein phosphorylation is a final common pathway through which a wide variety of regulatory compounds exert diverse biological effects in nervous, as well as in non-nervous, tissue (Greengard, 1978). One approach to elucidate the molecular mechanisms of those biological processes that involve protein phosphorylation is to detect and study those proteins in intact or broken cell preparations whose phosphorylation is regulated by endogenous protein kinases. Over the past several years, specific substrate proteins for cyclic AMP-dependent, cyclic GMP-dependent, and calcium/calmodulin-dependent protein kinases have been identified in nervous tissue (Greengard, 1982). One such substrate protein is Protein I. Protein I is present only in neurons (Ueda and Greengard, 1977), where it is concentrated in presynaptic nerve terminals (De Camilli et al., 1979, 1980; Bloom et al., 1979; P. De Camilli, W. B. Huttner, M. Harris, R. Cameron, and P. Greengard, manuscript in preparation). Moreover, Pro-

This work was supported by United States Public Health Service Grants $\mathrm{MH}-17387$ and NS-08440 and by grants from Hoffmann-LaRoche and the McKnight Foundation.

"To whom correspondence should be addressed at Department of Pharmacology, Yale University School of Medicine, P.O. Box 3333, 333 Cedar Street, New Haven, CT 06510. tein I appears to be present in a large majority of, and possibly in all, presynaptic nerve terminals (De Camilli et al., 1980; P. De Camilli, W. B. Huttner, M. Harris, R. Cameron, and P. Greengard, manuscript in preparation), where it is at least partially associated with neurotransmitter vesicles (Ueda et al., 1979; Bloom et al., 1979; Fried et al., 1982; P. De Camilli, W. B. Huttner, M. Harris, R. Cameron, and P. Greengard, manuscript in preparation). Protein $I$ is an endogenous substrate in nervous tissue for both cyclic AMP-dependent (Ueda and Greengard, 1977) and calcium/calmodulin-dependent (Krueger et al., 1977; Huttner and Greengard, 1979; Kennedy and Greengard, 1981) protein kinases. Protein I contains one serine residue in the collagenase-insensitive region of the molecule that is phosphorylated by both a cyclic AMP-dependent and a calcium/calmodulindependent protein kinase and two serine residues in the collagenase-sensitive region of the molecule that are phosphorylated by a second calcium/calmodulin-dependent protein kinase (Huttner et al., 1981; Kennedy and Greengard, 1981). The neurotransmitters serotonin and dopamine, apparently acting through cyclic AMP (Dolphin and Greengard, 1981a, b; Nestler and Greengard, 1980), and depolarizing agents, apparently acting through calcium (Forn and Greengard, 1978; Dolphin and Greengard, 1981b; Nestler and Greengard, 1980), have been 
shown to increase the state of phosphorylation of Protein $I$ in intact preparations of the central and peripheral nervous systems. In those studies, however, it was not possible to determine whether the observed changes in Protein I phosphorylation occurred presynaptically or postsynaptically. Furthermore, a question related to whether neurotransmitters and depolarizing agents regulate Protein I phosphorylation, is whether nerve impulse conduction also might regulate Protein I phosphorylation and, if so, whether such regulation occurs presynaptically or postsynaptically. To answer these questions, we chose to study Protein I phosphorylation in the rabbit superior cervical ganglion, a well characterized neuronal preparation that is suitable for both physiological and biochemical studies. In the present study, we have determined the distribution of Protein $I$ in the ganglion and show that impulse conduction and dopamine increase the state of phosphorylation of presynaptic Protein I but not that of postsynaptic Protein I.

\section{Materials and Methods}

Surgical denervation. Female New Zealand white rabbits (1.5 to $2.5 \mathrm{~kg}$ ) were used for denervation studies of the superior cervical ganglion. Rabbits were anesthetized with methoxyflurane (Pitman-Moore); surgery was performed under aseptic conditions. The cervical sympathetic nerve was ligated and transected approximately 2 $\mathrm{cm}$ proximal to the ganglion either unilaterally or bilaterally. Animals were used 1 to 4 weeks after surgery by which time denervation is complete (Ostberg et al., 1976; Raine and Chubb, 1977; Nja and Purves, 1978). The activity of choline acetyltransferase in denervated ganglia was less than $5 \%$ of that in intact ganglia, indicating the success of the denervation (choline acetyltransferase activity was kindly assayed by Edwin Meyer, Yale University).

Inhibition of protein synthesis in vivo. Female $\mathrm{Ne}$. Zealand White rabbits ( 1.5 to $2.5 \mathrm{~kg}$ ) and male SpragueDawley rats (150 to $200 \mathrm{gm}$ ) were injected subcutaneously with cycloheximide (Sigma; $30 \mathrm{mg} / \mathrm{kg}$ ) every $4 \mathrm{hr}$. This schedule has been shown to inhibit protein synthesis in vivo ( $\mathrm{Yu}$ and Feigelson, 1972). Control animals were injected subcutaneously with $50 \%$ ethanol, the vehicle used for the cycloheximide injections. The animals were killed $4 \mathrm{hr}$ after the last injection and sodium dodecyl sulfate (SDS) extracts were prepared from rabbit superior cervical ganglia and rat adrenal medullae as described below. The longest period of protein synthesis inhibition studied was $8 \mathrm{hr}$ (i.e., two injections of cycloheximide) because the animals did not consistently survive longer periods of exposure to cycloheximide.

The efficacy of cycloheximide treatment was confirmed in rabbits using a modification of the procedure of Rainbow et al. (1980a). The level of protein synthesis observed in superior cervical ganglia from a rabbit sacrificed $2 \mathrm{hr}$ after a single injection of cycloheximide was $33 \%$ of that observed in ganglia from a control rabbit. These data indicate a degree of protein synthesis inhibition comparable to that observed in other studies (Rainbow et al., 1980a, b).

Radioimmunoassay of Protein I. The Protein I content of rabbit superior cervical ganglia and rat adrenal medullae was determined in triplicate by a detergentbased radioimmunoassay (Goelz et al., 1981). The tissue samples to be assayed were homogenized in $1 \%$ SDS (approximately $4 \mathrm{mg}$ of protein $/ \mathrm{ml}$ ) and boiled for $5 \mathrm{~min}$. The boiled SDS homogenates then were centrifuged in a Beckman Microfuge for 2 min. The supernatant fluids ("SDS extracts"), which contained all of the Protein I, were either assayed immediately or frozen and stored for up to 2 days at $-20^{\circ} \mathrm{C}$ before being assayed. SDS extracts of ganglion and adrenal medulla competed in the assay in a manner parallel to Protein I purified from rat or bovine brain, indicating the immunological similarity of the Protein I from the different sources.

Radioimmunolabeling of Protein I in polyacrylamide gels. SDS extracts of rabbit superior cervical ganglia were subjected to SDS-polyacrylamide gel electrophoresis as previously described (Ueda and Greengard, 1977). Each gel included several concentrations of pure Protein I for comparison. At the completion of electrophoresis, the gels were fixed for $2 \mathrm{hr}$ in $50 \%$ methanol, $10 \%$ acetic acid, $40 \% \mathrm{H}_{2} \mathrm{O}(\mathrm{v} / \mathrm{v} / \mathrm{v})$ and washed for $2 \mathrm{hr}$, with several changes, in a buffer containing $150 \mathrm{~mm} \mathrm{NaCl}, 50 \mathrm{~mm}$ Tris ( $\mathrm{pH} 7.4), 0.05 \%$ sodium azide (w/v). The gels then were radioimmunolabeled according to the procedure of Adair et al. (1978) as modified for Protein I (De Camilli et al., 1979). Briefly, the washed gels were incubated in antiserum (1:250 dilution in $\mathrm{NaCl} / \mathrm{Tris} /$ sodium azide buffer; the volume of diluted antiserum was twice the volume of the gel) for $6 \mathrm{hr}$ and washed in an excess volume of $\mathrm{NaCl}$ / Tris/sodium azide buffer for $15 \mathrm{hr}$ with several changes. The gels then were incubated in ${ }^{125}$ I-labeled Protein A $\left(2 \times 10^{6} \mathrm{cpm} / \mathrm{ml}\right.$ of $\mathrm{NaCl} /$ Tris/sodium azide buffer; the volume of the Protein A solution was twice the volume of the gel) for $6 \mathrm{hr}$ and washed in an excess volume of $\mathrm{NaCl} /$ Tris/sodium azide buffer for $15 \mathrm{hr}$ with several changes. The gels were dried, immunolabeled Protein I bands were identified by autoradiography, and the ${ }^{125} \mathbf{I}$ content of the bands was measured in a Beckman Biogamma II. By comparing the ${ }^{125}$ I labeling of the Protein I in tissue samples to that of purified Protein I, an estimation of the amount of Protein $I$ in the tissue samples was achieved.

Isolation, incubation, and stimulation of rabbit superior cervical ganglia. Female New Zealand White rabbits ( 1.5 to $2.5 \mathrm{~kg}$ ), with intact or denervated superior cervical ganglia, were injected intravenously with $1 \mathrm{ml}$ (50 mg) of sodium pentobarbital (Nembutal, Abbott) and then killed by air embolism. The two superior cervical ganglia of each rabbit with their pre- and postganglionic nerves were dissected quickly, placed into a chamber, and superfused at room temperature with oxygenated Locke's buffer of the following composition: $136 \mathrm{~mm}$ $\mathrm{NaCl}, 5.6 \mathrm{~mm} \mathrm{KCl}, 20 \mathrm{~mm} \mathrm{NaHCO}, 1.2 \mathrm{~mm} \mathrm{NaH}_{2} \mathrm{PO}_{4}$, $2.2 \mathrm{mM} \mathrm{CaCl}_{2}, 1.2 \mathrm{~mm} \mathrm{MgCl}_{2}, 0.18 \%$ glucose (pH 7.4). The ganglia were decapsulated carefully during superfusion and then superfusion was continued for an additional 30 to $60 \mathrm{~min}$. One ganglion from each rabbit served as the "test" ganglion and the other was the control. Test ganglia were treated in a variety of ways. For the experiments on impulse conduction, the preganglionic nerve (or, in some cases, the postganglionic nerves) supplying the test ganglion was stimulated via a suction electrode 
with supramaximal pulses for various durations at various frequencies. The effectiveness of the stimulation was monitored by recording compound action potentials from postganglionic nerves via a second suction electrode. For the experiments on dopamine and other compounds, test ganglia were transferred to a vial containing the appropriate compound in 5 to $10 \mathrm{ml}$ of oxygenated Locke's buffer. Ascorbate $(0.01 \%)$ was always included in buffer containing dopamine; ascorbate per se did not alter the results of the experiments. For the experiments on high $\mathrm{K}^{+}$concentration, test ganglia were transferred to a vial containing 5 to $10 \mathrm{ml}$ of oxygenated modified buffer $(60$ $\mathrm{mm} \mathrm{KCl}, 81.6 \mathrm{~mm} \mathrm{NaCl}$ ). As a control, some test ganglia were either mounted in suction electrodes and not stimulated or transferred to a vial containing oxygenated Locke's buffer. Following the experimental manipulations, test and contralateral control ganglia were homogenized in $400 \mu \mathrm{l}$ of $1 \%$ SDS using conical glass tissue homogenizers (Bellco). The SDS homogenates were boiled for $5 \mathrm{~min}$ and then centrifuged for $2 \mathrm{~min}$ in a Beckman Microfuge. The supernatants, referred to as "SDS extracts," contained essentially all of the Protein I as determined by radioimmunolabeling of the gels. SDS extracts were used to quantitate the amount of dephospho-Protein I and the amount of total Protein I.

Quantitation of the state of phosphorylation of Protein I. Dephospho-Protein I was assayed by a "back phosphorylation" technique according to which the Protein I in SDS extracts was first immunoprecipitated and then phosphorylated with purified protein kinases. The immunoprecipitation reaction was carried out at 0 to $4^{\circ} \mathrm{C}$ in plastic Microfuge tubes. Aliquots $(60 \mu \mathrm{l})$ of SDS extracts were adjusted by the addition of a $200-\mu$ l solution to contain (final concentrations): $250 \mathrm{~mm} \mathrm{NaCl}, 50 \mathrm{~mm}$ $\mathrm{NaF}, 14 \mathrm{~mm}$ EDTA, $10 \mathrm{~mm}$ sodium phosphate $(\mathrm{pH} 7.4)$, $1.5 \%(\mathrm{v} / \mathrm{v})$ Nonidet P-40. Four microliters of the $\gamma$-globulin fraction of Protein I antiserum (prepared as described by Campbell et al., 1970) was added to the SDS extract. The mixture was incubated for $20 \mathrm{~min}$ after which time $3 \mu \mathrm{g}$ of purified rabbit IgG (Sigma) and $20 \mu \mathrm{l}$ of the IgG fraction of goat anti-rabbit IgG (Sigma; $1 \mathrm{ml}$ of goat IgG was able to precipitate 2 to $3 \mathrm{mg}$ of rabbit IgG) were added. After a 3- to 4-hr incubation period, the mixture was centrifuged in a Microfuge for $1 \mathrm{~min}$. The pellet was washed with $200 \mu \mathrm{l}$ of ice cold $150 \mathrm{~mm}$ $\mathrm{NaCl}, 10 \mathrm{~mm}$ sodium phosphate (pH 7.4), $0.02 \% \mathrm{NaN}_{3}$ and then dissolved in $50 \mu \mathrm{l}$ of ice cold $11 \mathrm{~mm}$ citric acid (final $\mathrm{pH}, \sim 3$ ).

The dissolved pellet was phosphorylated as described (Nestler and Greengard, 1980) with the following modifications. The assay mixture (final volume, $70 \mu \mathrm{l}$ ) contained: $50 \mathrm{~mm}$ HEPES ( $\mathrm{pH} 7.4$ ), $10 \mathrm{~mm} \mathrm{MgCl}_{2}, 0.1 \mu \mathrm{M}$ purified catalytic subunit (beef heart cyclic AMP-dependent protein kinase; kindly provided by Angus C. Nairn of our laboratory), $15 \mathrm{~mm}$ dithiothreitol, $0.005 \%(\mathrm{v} / \mathrm{v})$ Nonidet P-40. The phosphorylation reaction was initiated by the addition of $30 \mu \mathrm{l}$ of $\left[\gamma-{ }^{32} \mathrm{P}\right] \mathrm{ATP}$ (final concentration, 2 to $3 \mu \mathrm{M}$; specific activity, 0.5 to $1 \times 10^{8} \mathrm{cpm} /$ nmol; prepared according to the method of Glynn and Chapell, 1964) and was carried out for $30 \mathrm{~min}$ at $30^{\circ} \mathrm{C}$. The reaction was terminated by boiling the mixture in "SDS-stop solution" of the following composition (final concentrations): $50 \mathrm{~mm}$ Tris. $\mathrm{HCl}(\mathrm{pH} 6.7), 4 \%(\mathrm{v} / \mathrm{v})$ glycerol, $2 \%$ (v/v) 2-mercaptoethanol, $2 \%$ SDS, with bromophenol blue as a marker. The boiled phosphorylated extract then was subjected to SDS-polyacrylamide gel electrophoresis as described (Nestler and Greengard, 1980) except that the lower (resolving) gel contained 9\% acrylamide with a ratio of acrylamide to methylenebisacrylamide of $30: 1.6$. The ${ }^{32} \mathrm{P}$ contained in the Protein I region of dried gels was located by autoradiography and measured using Cerenkov radiation. Each ganglion extract was immunoprecipitated and phosphorylated in duplicate. Under the conditions used, phosphorylation of Protein I was maximal and was linear over a 10-fold concentration range of ganglion extract. The recovery of both ${ }^{125} \mathrm{I}$-labeled and ${ }^{32} \mathrm{P}$-labeled pure Protein I, added to the SDS ganglion extract prior to immunoprecipitation, in the final immunoprecipitate was about $95 \%$. Moreover, the amount of phosphate that could be incorporated per mol of pure Protein I was not affected by the immunoprecipitation procedure (data not shown).

One-dimensional peptide mapping (Cleveland et al., 1977) was used to analyze the sites in Protein I that were phosphorylated under the assay conditions used. Gel slices containing ${ }^{32} \mathrm{P}$-labeled holo-Protein I were soaked in $5 \mathrm{ml}$ of $125 \mathrm{~mm}$ Tris ( $\mathrm{pH} \mathrm{6.7),} \mathrm{0.1 \%} \mathrm{SDS} \mathrm{for} 10 \mathrm{~min}$ at room temperature and then placed into the sample wells of a polyacrylamide gel. Each gel slice was overlaid with 50 to $100 \mu \mathrm{l}$ of $125 \mathrm{~mm}$ Tris (pH 6.7), 0.1\% SDS, 20\% glycerol with bromophenol blue as a marker and then overlaid with $5 \mu \mathrm{g}$ of Staphylococcus aureus V8 protease (Miles) in $20 \mu \mathrm{l}$ of $125 \mathrm{~mm}$ Tris ( $\mathrm{pH} 6.7$ ), $0.1 \%$ SDS, $10 \%$ glycerol with pyronin $\mathrm{y}$ as a marker. The concentration of acrylamide in the lower (resolving) gel was $15 \%$ with a ratio of acrylamide to methylenebisacrylamide of 30:0.8. Electrophoresis was carried out at $60 \mathrm{~V}$. At the completion of electrophoresis, the gels were dried and ${ }^{32} \mathrm{P}$-labeled fragments of Protein I were identified by autoradiography. The ${ }^{32} \mathrm{P}$ contained in the bands then was quantitated by liquid scintillation spectrometry. Two major phosphopeptide fragments result when Protein I is digested by this technique (Huttner and Greengard, 1979). The one phosphorylation site in the collagenase-insensitive region of Protein $I$, which is an endogenous substrate for both a cyclic AMP-dependent and a calcium/calmodulin-dependent protein kinase, is contained in a $M_{\mathrm{r}}=$ 10,000 fragment. The two phosphorylation sites in the collagenase-sensitive region of Protein I, which are endogenous substrates for a second calcium/calmodulindependent protein kinase, are contained in a $M_{\mathrm{r}}=34,000$ fragment (Huttner and Greengard, 1979; Kennedy and Greengard, 1981). Most of the ${ }^{32} \mathrm{P}$ incorporated into Protein $I$ in ganglion extracts under the assay conditions used was recovered in the $M_{\mathrm{r}}=10,000$ fragment. A small amount of ${ }^{32} \mathrm{P}$ was recovered in the $M_{\mathrm{r}}=34,000$ fragment. (Even though the sites in the $M_{\mathrm{r}}=34,000$ fragment are not endogenous substrates for cyclic AMP-dependent protein kinase, a sufficiently high concentration of the kinase was used in the assay intentionally in order to partially phosphorylate these sites.) Under the pcptidemapping conditions used, the amount of ${ }^{32} \mathrm{P}$ recovered in the two phosphopeptide fragments was typically $65 \%$ of that present in the holo-Protein I starting material. Be- 
cause of the much larger amount of phosphate incorporated into the $M_{\mathrm{r}}=10,000$ fragment, changes observed in holo-Protein I were more indicative of changes in the $M_{\mathrm{r}}$ $=10,000$ fragment than of those in the $M_{\mathrm{r}}=34,000$ fragment.

The total amount of Protein I in each ganglion extract was determined in triplicate by radioimmunoassay (Goelz et al., 1981). The assay was linear over a 10 -fold concentration range of rabbit ganglion extract. Under resting conditions, the two ganglia of a rabbit contained equivalent amounts of Protein I (the left ganglion contained $101 \pm 5 \%$ of the amount of Protein I contained in the right ganglion; mean $\pm \mathrm{SEM}$; six pairs of ganglia). In addition, none of the experimental treatments used in this study significantly altered the total Protein I content of test ganglia compared to that of contralateral control ganglia. Thus, the changes observed in the amount of dephospho-Protein $I$ in test ganglia compared to that in control ganglia reflected changes in the state of phosphorylation of Protein I and not changes in the total amount of Protein I.

Peptide-mapping analysis of Protein I in extracts of control ganglia revealed that, under the assay conditions used, $0.78 \pm 0.03 \mathrm{~mol}$ of phosphate was incorporated per mol of Protein I in the phosphorylation site in the collagenase-insensitive region of the molecule (mean \pm SEM; 20 ganglia). Similar amounts of phosphate were incorporated into this phosphorylation site when either pure Protein I or Protein I from control denervated ganglia was used (data not shown). In previous studies, only about $0.2 \mathrm{~mol}$ of phosphate could be incorporated into this site maximally per mol of pure Protein I (Huttner et al., 1981) or of bovine ganglion Protein I (Nestler and Greengard, 1980). It was found (data not shown) that the improved incorporation of phosphate into Protein I observed in the present studies was due to the presence of both dithiothreitol and a trace amount of Nonidet P-40 in the phosphorylation reaction mixture. Presumably, these agents inhibit the aggregation of Protein I and thereby improve the accessibility of Protein I to the protein kinase. In support of this interpretation, Walter and Blobel (1980) found that trace amounts of a nonionic detergent were necessary to prevent the aggregation of another extrinsic membrane protein. The ability to incorporate about $0.8 \mathrm{~mol}$ of phosphate into this site per mol of Protein I from control intact and control denervated rabbit ganglia indicates that the large majority of the Protein I in both types of control ganglia was present in the dephosphorylated form. In contrast to the phosphorylation site in the collagenase-insensitive region of Protein I, only $0.13 \pm 0.01 \mathrm{~mol}$ of phosphate was incorporated per mol of Protein I in the phosphorylation sites in the collagenase-sensitive region of the molecule from control intact ganglion (mean \pm SEM; 20 ganglia). Similar amounts of phosphate were incorporated into these phosphorylation sites of Protein I from control denervated ganglion (data not shown). The reason for the low level of phosphate incorporated into the collagenase-sensitive region of Protein $\mathrm{I}$ is not known.

Comments on the quantitation of dephospho-Protein $I$ in the rabbit superior cervical ganglion. It proved necessary to develop the procedure described in the previous section for quantitating the amount of dephospho-Protein I in rabbit ganglia. This was because the technique used previously (Forn and Greengard, 1978) to quantitate the amount of dephospho-Protein $I$ in rat cerebral cortex slices was found to be not applicable to a study of Protein I in rabbit superior cervical ganglion. According to the technique used earlier, brain slices were homogenized in the presence of $\mathrm{Zn}^{2+}$, which prevented changes during homogenization in the state of phosphorylation of Protein I by inhibiting endogenous kinase and phosphatase activities. Protein I then was solubilized from the particulate fraction of the homogenate by rehomogenizing the sample in $\mathrm{pH} 3$ buffer. The $\mathrm{pH} 3$ extract was neutralized and then "back phosphorylated" with purified protein kinase. Obviously, this procedure can only be used to assay dephospho-Protein I in those tissues from which Protein I can be solubilized from $\mathrm{Zn}^{2+}$ pellets by $\mathrm{pH} 3$. Homogenization in $\mathrm{pH} 3$ did not solubilize Protein I from $\mathrm{Zn}^{2+}$ pellets either of rabbit superior cervical ganglion or of many other peripheral nervous tissues studied. The explanation for the failure of $\mathrm{pH} 3$ to solubilize Protein I from $\mathrm{Zn}^{2+}$ pellets of these tissues remains unknown.

Studies of the extraction properties of Protein I present in rabbit superior cervical ganglion showed that, of the many conditions tried, only homogenization and boiling in $1 \%$ SDS consistently and completely solubilized Protein I as determined by radioimmunolabeling of gels (data not shown). These extraction properties necessitated the development of a procedure to quantitate the amount of dephospho-Protein I in SDS tissue extracts. Since protein kinase activity is destroyed by ionic detergents, it was necessary to remove the SDS from the Protein I prior to back phosphorylation. This was accomplished by immunoprecipitating the Protein I from solution with Protein I antiserum and goat anti-rabbit IgG. The resulting immune pellet was dissolved in $\mathrm{pH} 3(\mathrm{pH}$ 3 disrupts immune complexes; Campbell et al., 1970) and the solution then was neutralized in the presence of 15 mM dithiothreitol (dithiothreitol denatures immunoglobulins; Parkhouse et al., 1970). The Protein I, now purified with respect to other ganglion proteins and SDS, was phosphorylated with purified protein kinase. Figure 1 shows examples of phosphorylated immunoprecipitates, analyzed by SDS-polyacrylamide gel electrophoresis, when ganglion extract was excluded from (left lane) and included in (right lane) the immunoprecipitation mixture. The phosphoproteins in the left lane, therefore, represent serum proteins. Only one additional major phosphoprotein, a doublet, was observed in back phosphorylated immunoprecipitates when ganglion extract was included in the immunoprecipitation mixture. This phosphoprotein was indistinguishable from pure Protein I by apparent molecular weight and by secondary oneand two-dimensional peptide-mapping analysis (Huttner and Greengard, 1979; data not shown).

\section{Results}

Effect of denervation. All of the Protein I detected immunocytochemically in the superior cervical ganglion appeared to be presynaptic (De Camilli et al., 1979; P. De Camilli, S. B. Huttner, M. Harris, R. Cameron, and 


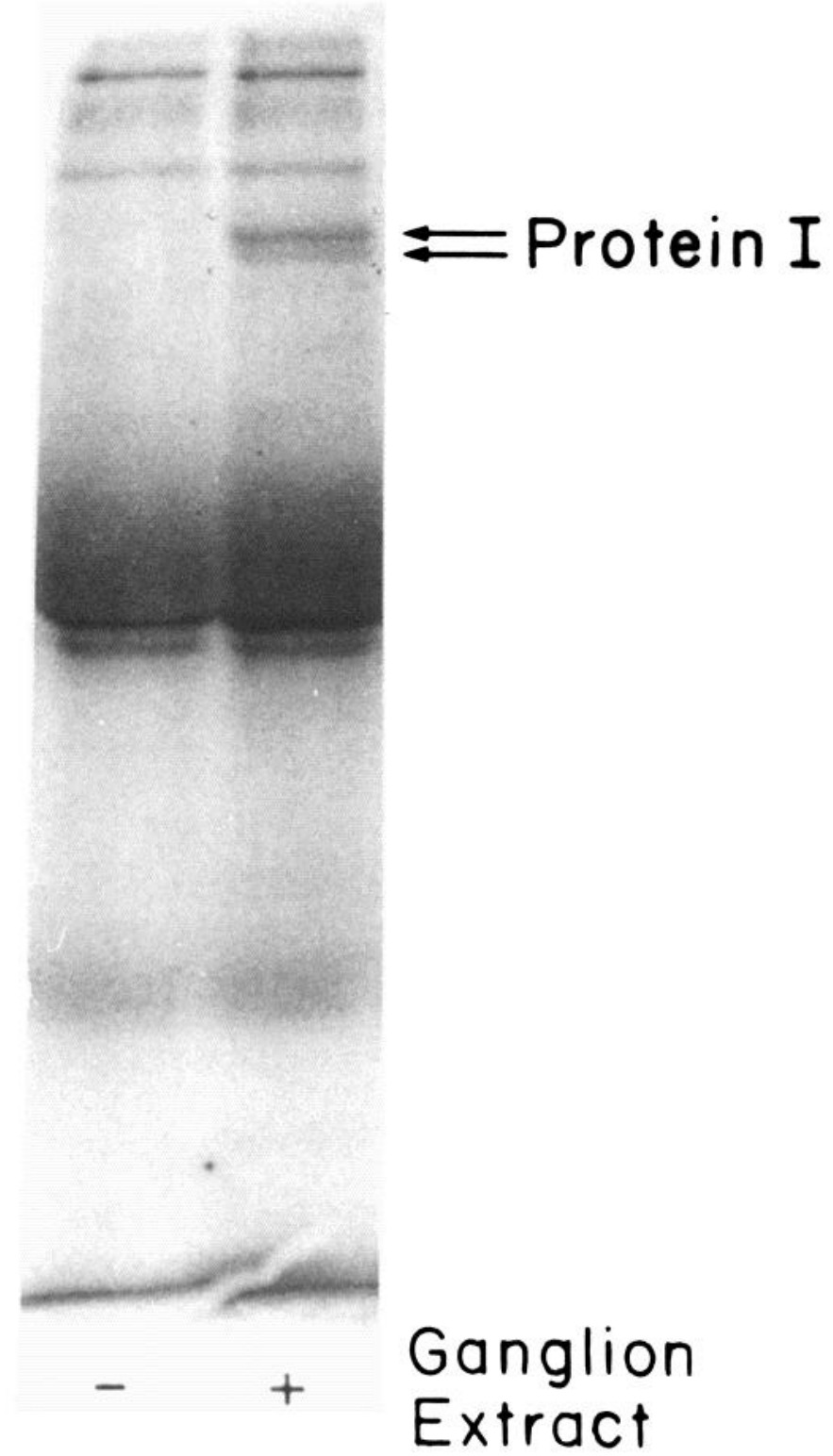

Figure 1. Autoradiograph showing the proteins that are "back phosphorylated" in immunoprecipitates. Protein I antiserum, rabbit IgG, and goat anti-rabbit IgG were added to 60 $\mu \mathrm{l}$ of $1 \%$ SDS (left lane) or to $60 \mu \mathrm{l}$ of SDS extract of rabbit superior cervical ganglion (right lane). The resulting immunoprecipitates were back phosphorylated and subjected to SDSpolyacrylamide gel electrophoresis.

P. Greengard, manuscript in preparation); no Protein I was detected in the cell bodies of ganglionic neurons. The distribution of Protein I between presynaptic and postsynaptic elements now has been studied further by examining the effect of denervation on the Protein $I$ content of the superior cervical ganglion. The superior cervical ganglion consists predominantly of presynaptic cholinergic nerve terminals and postsynaptic ganglionic cell bodies. Transection of the cervical sympathetic (preganglionic) nerve has been shown to destroy about $95 \%$ of the nerve endings in the ganglion as determined by ultrastructural morphometry (Ostberg et al., 1976). In contrast, the level of Protein I in denervated ganglia, measured by radioimmunoassay, was about $40 \%$ of that in contralateral intact ganglia (Table I). Thus, it would appear that about $60 \%$ of the total ganglion Protein $\mathrm{I}$ is presynaptic and $40 \%$ is postsynaptic.

Effect of inhibition of protein synthesis in vivo. The presence of Protein I in denervated superior cervical ganglia suggested that the cell bodies of ganglionic neurons contain Protein I. Possibly, Protein I contained in the cell bodies represents newly synthesized Protein I that is about to be transported to the nerve terminals elaborated by the cell bodies. This possibility was studied by determining the effect of cycloheximide, a protein synthesis inhibitor, on the Protein I content of intact and denervated rabbit superior cervical ganglia. A short period $(8 \mathrm{hr})$ of protein synthesis inhibition in vivo decreased the level of Protein I in intact ganglia by about $20 \%$ and in denervated ganglia by about $50 \%$ (Table II; Fig. 2). The cycloheximide-induced decrease in Protein I was approximately the same in denervated ganglia (214 $\mathrm{fmol})$ as it was in intact ganglia $(223 \mathrm{fmol})$. Similarly, the denervation-induced decrease in Protein I was approximately the same in cycloheximide-treated ganglia $(612$ fmol) as it was in control ganglia $(621 \mathrm{fmol})$. In contrast to the superior cervical ganglion, exposure of rats to cycloheximide for $8 \mathrm{hr}$ did not alter the Protein I content of the adrenal medulla (data not shown).

Regulation of Protein I phosphorylation in the rabbit superior cervical ganglion. When the preganglionic nerve supplying a rabbit ganglion was stimulated for 30 sec at $10 \mathrm{~Hz}$, a frequency of impulse conduction observed in vivo (Douglas and Ritchie, 1957), there was a decrease

TABLE I

Effect of denervation on Protein I levels in rabbit superior cervical ganglia

One superior cervical ganglion of each rabbit was denervated, and 1 to 4 weeks after denervation, the Protein I content of denervated and of contralateral intact ganglia was determined by radioimmunoassay. Data are expressed as the mean \pm SEM. The numbers in parentheses represent the number of ganglia.

\begin{tabular}{lcc}
\hline \multirow{2}{*}{ Ganglion } & \multicolumn{2}{c}{ Protein I } \\
\cline { 2 - 3 } & Fmol/Ganglion & Percent Intact Ganglion \\
\hline Intact & $937 \pm 87(18)$ & \\
Denervated & $332 \pm 28(18)$ & $38 \pm 2(18)$ \\
\hline
\end{tabular}

TABLE II

Effect of cycloheximide on Protein I levels in intact and denervated rabbit superior cervical ganglia

Rabbits were exposed to cycloheximide for $8 \mathrm{hr}$ as described under "Materials and Methods" and the Protein I content of superior cervical ganglia was determined by radioimmunoassay. Data are expressed as the mean \pm SEM. The numbers in parentheses represent the number of ganglia.

\begin{tabular}{lccc}
\hline \multirow{2}{*}{ Condition } & Protein I \\
\cline { 2 - 4 } & & Denervated & $\begin{array}{c}\text { Intact - } \\
\text { Denervated }\end{array}$ \\
\hline & & fmol/ganglion \\
Control & $1039 \pm 77(14)$ & $418 \pm 18(14)$ & 621 \\
Cycloheximide & $816 \pm 64(14)$ & $204 \pm 22(14)$ & 612 \\
Control - & 223 & 214 & \\
$\quad$ Cycloheximide & & & \\
\hline
\end{tabular}




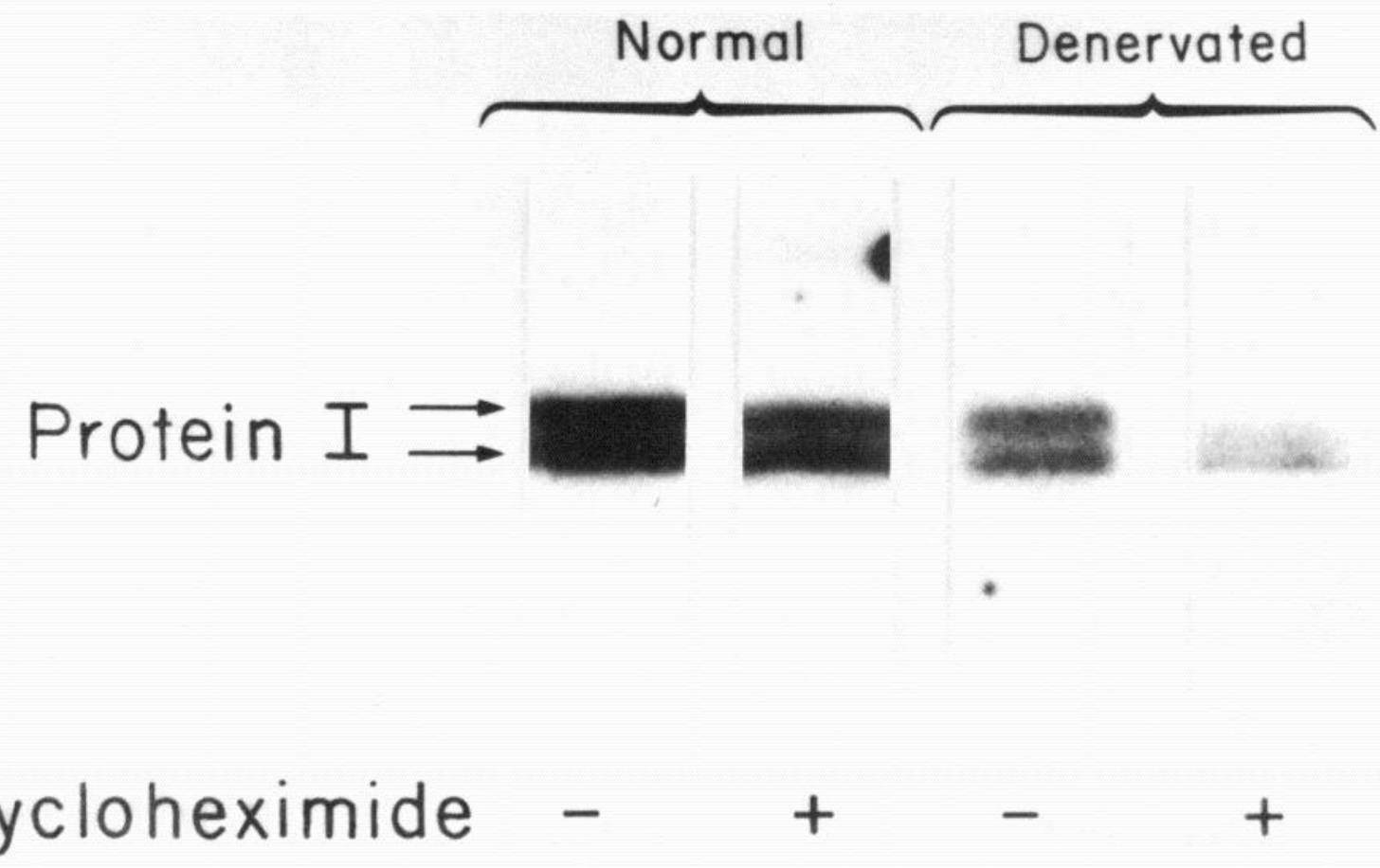

Figure 2. Autoradiograph of a gel radioimmunolabeled for Protein I illustrating the effect of cycloheximide on Protein I levels in normal and denervated rabbit superior cervical ganglion. Rabbits with intact or denervated ganglia were exposed to cycloheximide for $8 \mathrm{hr}$. Control rabbits received vehicle injections. SDS extracts were prepared from ganglia and $70 \mu \mathrm{l}$ of each extract (400 $\mu \mathrm{l}$ /ganglion) were subjected to SDS-polyacrylamide gel electrophoresis. The gel then was radioimmunolabeled for Protein I.

in the amount of dephospho-Protein I in stimulated ganglia compared to that in contralateral control ganglia (Fig. 3; Table III). In contrast, the two ganglia of each rabbit contained equivalent amounts of dephospho-Protein I when neither ganglion was stimulated (Fig. 3; Table III). In addition, dopamine, under conditions which produced physiological effects in rabbit ganglia (Libet, 1970; Dun and Nishi, 1974) and decreased the amount of dephospho-Protein I in bovine ganglion sections (Nestler and Greengard, 1980), also decreased the amount of dephospho-Protein I in rabbit ganglia (Fig. 4; Table III). Denervated ganglia contained about $40 \%$ of the amount of dephospho-Protein I contained in intact control ganglia (Fig. 4; Table III). Dopamine did not decrease the lowered amount of dephospho-Protein I in denervated rabbit ganglia further (Fig. 4; Table III), in contrast to the effect of dopamine in intact ganglia. Similarly, a high $\mathrm{K}^{+}$concentration, under conditions which decreased the amount of dephospho-Protein I in bovine ganglion sections (Nestler and Greengard, 1980), decreased the amount of dephospho-Protein I in intact, but not in denervated, rabbit superior cervical ganglia (Fig. 5; Table III). Since the total amount of Protein I, determined by radioimmunoassay, was not altered significantly by nerve impulse conduction, by dopamine, or by a high $\mathrm{K}^{+}$concentration, the results demonstrate that these three manipulations increase the state of phosphorylation of Protein $I$ in intact rabbit superior cervical ganglia.

In contrast to orthodromic impulse conduction (stimulation of preganglionic nerves), antidromic impulse conduction (stimulation of postganglionic nerves) failed to alter Protein I phosphorylation (Table III). The effect of dopamine on Protein I phosphorylation was blocked when ganglia were preincubated in phenoxybenzamine, a ganglionic dopamine receptor antagonist (Libet, 1970; Kalix et al., 1974). In contrast, the effect of nerve impulse conduction on Protein I phosphorylation was not blocked when ganglia were preincubated in phenoxybenzamine plus hexamethonium (a nicotinic cholinergic antagonist) plus atropine (a muscarinic cholinergic antagonist), conditions which abolish the three postsynaptic potentials observed in the rabbit superior cervical ganglion (Kosterlitz and Wallis, 1966; Libet, 1970; Kalix et al., 1974; McAfee et al., 1980) (Table III). Moreover, 8-bromocyclic AMP, under conditions which increased Protein I phosphorylation in bovine ganglion sections (Nestler and Greengard, 1980), also increased the state of phosphorylation of Protein I in rabbit ganglia (Table III). In addition to 8-bromo-cyclic AMP, forscolin, which activates adenylate cyclase in intact tissue preparations (Seamon et al., 1981), also increased the state of phosphorylation of Protein I in rabbit ganglia (Table III).

The effects of nerve impulse conduction and of a high $\mathrm{K}^{+}$concentration, but not those of dopamine and of 8bromo-cyclic AMP, were abolished under calcium-free conditions (Table III). The inability of nerve impulse conduction to increase Protein I phosphorylation under calcium-free conditions was not a result of the deterioration of the preparation. Thus, returning ganglia, which had been preincubated in calcium-free Locke's solution, to calcium-containing Locke's solution for $15 \mathrm{~min}$ restored the ability of nerve impulse conduction to increase Protein I phosphorylation (data not shown).

Analysis of phosphorylation sites. Several of the ex- 


\section{Experimental Rabbit}

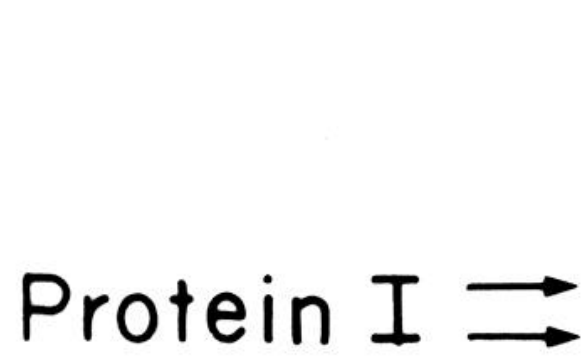

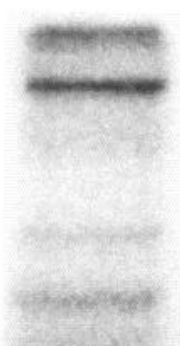

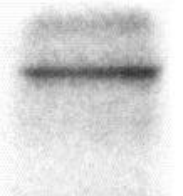

Control Rabbit
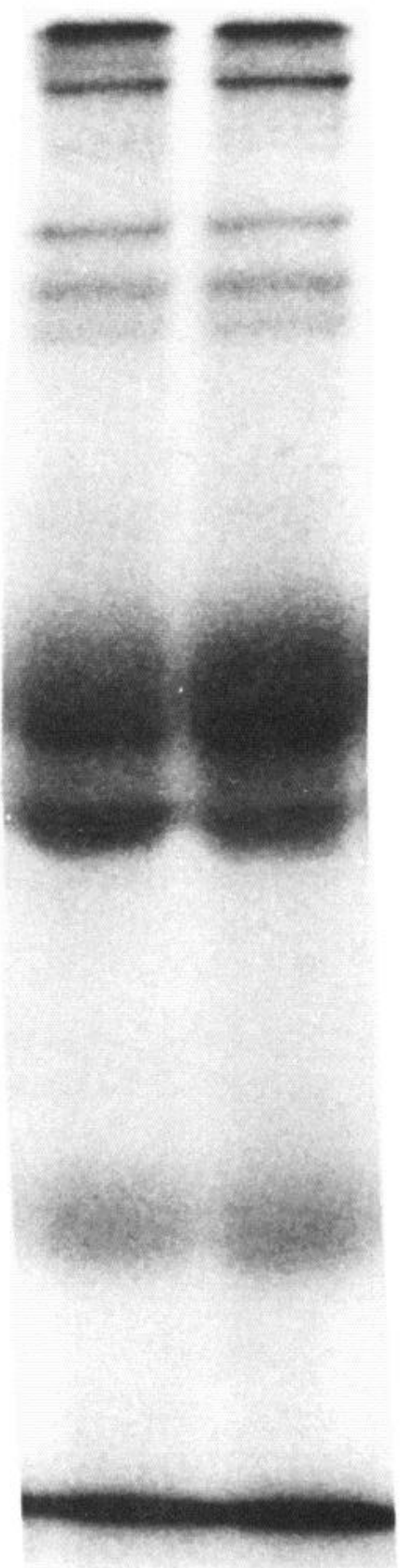

left right

\section{Ganglion left right}

\section{Nerve \\ Stimulation}

Figure 3. Autoradiograph showing the effect of impulse conduction on the state of phosphorylation of Protein I in the rabbit superior cervical ganglion. The preganglionic nerve of the right ganglion of a rabbit was stimulated via a suction electrode for 30 sec at $10 \mathrm{~Hz}$. The contralateral left ganglion and the two ganglia of a second rabbit were not stimulated. The ganglia then were homogenized in $1 \%$ SDS. The Protein I contained in the SDS extracts was immunoprecipitated, back phosphorylated, and subjected to SDS-polyacrylamide gel electrophoresis. 
TABLE III

Regulation of the state of phosphorylation of Protein I in rabbit superior cervical ganglia

Pairs of intact (A and B) and denervated (C) rabbit superior cervical ganglia were preincubated for 30 to 60 min in the following buffers: A and C, standard Locke's buffer (a to e, h, and i), standard Locke's buffer containing $100 \mu \mathrm{M}$ phenoxybenzamine (f), or standard Locke's buffer containing $100 \mu \mathrm{M}$ phenoxybenzamine, $0.5 \mathrm{~mm}$ hexamethonium, and $25 \mu \mathrm{M}$ atropine (g); B, calcium-free Locke's buffer (modified from standard buffer; $2.2 \mathrm{mM} \mathrm{MgCl} 2$ and $1 \mathrm{~mm}$ EGTA were substituted for $2.2 \mathrm{mM} \mathrm{CaCl}_{2}$ ) (a to $\mathrm{d}$ and $\mathrm{h}$ ). One ganglion of each rabbit served as the test ganglion and the other was the control. Test ganglia in A were treated in a variety of ways: (a) the preganglionic nerve was mounted in a suction electrode and not stimulated or the ganglion was transferred to a vial containing standard Locke's buffer; (b) the preganglionic nerve was mounted in a suction electrode and stimulated for $30 \mathrm{sec}$ at $10 \mathrm{~Hz}$; (c) the ganglion was transferred to a vial containing $100 \mu \mathrm{m}$ dopamine in standard Locke's buffer and incubated for $4 \mathrm{~min}$; (d) the ganglion was transferred to a vial containing modified Locke's buffer $\left(60 \mathrm{mM} \mathrm{K}^{+}\right)$and incubated for 1 min; (e) the postganglionic nerves were mounted in a suction electrode and stimulated for $30 \mathrm{sec}$ at $10 \mathrm{~Hz}$; (f) the ganglion was transferred to a vial containing $100 \mu \mathrm{M}$ dopamine and $100 \mu \mathrm{M}$ phenoxybenzamine in standard Locke's buffer and incubated for 4 min; (g) the preganglionic nerve was mounted in a suction electrode and stimulated for $30 \mathrm{sec}$ at $10 \mathrm{~Hz}$ in the presence of $100 \mu \mathrm{M}$ phenoxybenzamine, $0.5 \mathrm{~mm}$ hexamethonium, and 25 $\mu \mathrm{M}$ atropine; (h) the ganglion was transferred to a vial containing $4 \mathrm{mM}$ 8-bromo-cyclic AMP in standard Locke's buffer and incubated for $15 \mathrm{~min}$; and (i) the ganglion was transferred to a vial containing $100 \mu \mathrm{M}$ forscolin (Calbiochem/Behring Corp.) in standard Locke's buffer and incubated for $15 \mathrm{~min}$. Test ganglia in B were treated as were those in A except that calcium-free Locke's buffer was used in place of standard Locke's buffer. Test ganglia in $\mathrm{C}$ were treated as were those in $\mathrm{A}$. Incubations and stimulations were terminated by homogenizing test and contralateral control ganglia in $1 \%$ SDS. The amount of dephospho-Protein I in SDS extracts then was assayed and the amount of dephospho-Protein I in each test ganglion was compared to that in its contralateral control ganglion. Data are expressed as the mean \pm SEM. The numbers in parentheses represent the number of pairs of ganglia. Control denervated ganglia contained $46 \pm 5 \%$ (mean \pm SEM; four pairs of ganglia) of the amount of dephospho-Protein I contained in control intact ganglia.

\begin{tabular}{|c|c|c|c|}
\hline \multirow[b]{2}{*}{ Condition } & \multicolumn{3}{|c|}{ Dephospho-Protein I } \\
\hline & $\begin{array}{c}\text { (A) } \\
\text { Intact } \\
+ \text { Calcium }\end{array}$ & $\begin{array}{c}\text { (B) } \\
\text { Intact } \\
- \text { Calcium } \\
\end{array}$ & $\begin{array}{c}\text { (C) } \\
\text { Denervated } \\
+ \text { Calcium }\end{array}$ \\
\hline & \multicolumn{3}{|c|}{ \% contralatcral control } \\
\hline a. Control & $102 \pm 4 \quad(6)$ & $99 \pm 10$ & $107 \pm 6(3)$ \\
\hline b. Preganglionic nerve stimulation & $56 \pm 4^{a}$ & $102 \pm 6(6)$ & \\
\hline c. Dopamine & $69 \pm 3^{a}(10)$ & $68 \pm 3^{a}(7)$ & $102 \pm 3(5)$ \\
\hline d. High $\mathrm{K}^{+}$concentration & $54 \pm 3^{a} \quad(6)$ & $102 \pm 8(4)$ & $102 \pm 4(5)$ \\
\hline e. Postganglionic nerve stimulation & $99 \pm 4$ & & \\
\hline f. Dopamine + phenoxybenzamine & $102 \pm 5$ & & \\
\hline $\begin{array}{l}\text { g. Preganglionic nerve stimulation }+ \text { phen- } \\
\text { oxybenzamine, hexamethonium, and } \\
\text { atropine }\end{array}$ & $63 \pm 7^{\alpha}$ & & \\
\hline h. 8 Bromo-cyclic AMP & $61 \pm 4^{a}$ & $60 \pm 5^{a}(3)$ & \\
\hline i. Forscolin & $53 \pm 4^{\alpha}$ & & \\
\hline
\end{tabular}

"Significantly different from control $(p<0.05)$ by two-tailed $t$ test.

perimental conditions reported in Table III were found to regulate the state of phosphorylation of holo-Protein I. One-dimensional peptide mapping was used to determine which of the phosphorylation sites in Protein I were affected. As shown in Table IV, the decreases observed in dephospho-holo-Protein I (Table III) in response to nerve impulse conduction, to nerve impulse conduction in the presence of phenoxybenzamine, hexamethonium, and atropine, or to a high $\mathrm{K}^{+}$concentration were reflected in equivalent quantitative decreases in both the collagenase-insensitive (i.e., the $M_{\mathrm{r}}=10,000$ fragment) and collagenase-sensitive (i.e., the $M_{\mathrm{r}}=34,000$ fragment) regions of Protein I. In contrast, the decreases observed in dephospho-holo-Protein I (Table III) in response to dopamine, to 8-bromo-cyclic AMP, and to forscolin were reflected in statistically significant decreases only in the collagenase-insensitive (i.e., the $M_{\mathrm{r}}=10,000$ fragment) region of Protein I (Table IV). Dopamine also elicited a decrease in the collagenase-sensitive (i.e., $M_{\mathrm{r}}=34,000$ fragment) region of Protein I, but this decrease was not statistically significant (Table IV). Furthermore, Table IV shows that postganglionic nerve stimulation or dopamine in the presence of phenoxybenzamine, conditions which did not alter dephospho-holo-Protein I (Table III), also did not alter the phosphorylation state of either region of Protein I.

\section{Discussion}

Using a radioimmunoassay procedure to determine the total amount of Protein I, we have found that denervated ganglia contained $40 \%$ of the Protein I present in intact ganglia. Moreover, results obtained by assaying the amount of dephospho-Protein I, in denervated and intact ganglia, indicated a similar distribution. Thus, it appears that $60 \%$ of ganglion Protein I is located in presynaptic nerve terminals and the remainder is in the cell bodies. The inability to detect this postsynaptic Protein I by immunocytochemical methods (De Camilli et al., 1979) might be expected if the Protein $I$ in the cell bodies is present in a considerably lower concentration than that in the presynaptic nerve terminals.

Cycloheximide was shown to reduce Protein I levels by the same amount in intact and in denervated ganglia and, conversely, denervation was shown to reduce Protein I levels by the same amount in normal and in cycloheximide-treated ganglia. The simplest interpretation of these data is that the superior cervical ganglion contains two "pools" of Protein I: a presynaptic pool that 


\section{Intact Ganglia}

\section{Protein I $\longrightarrow$}

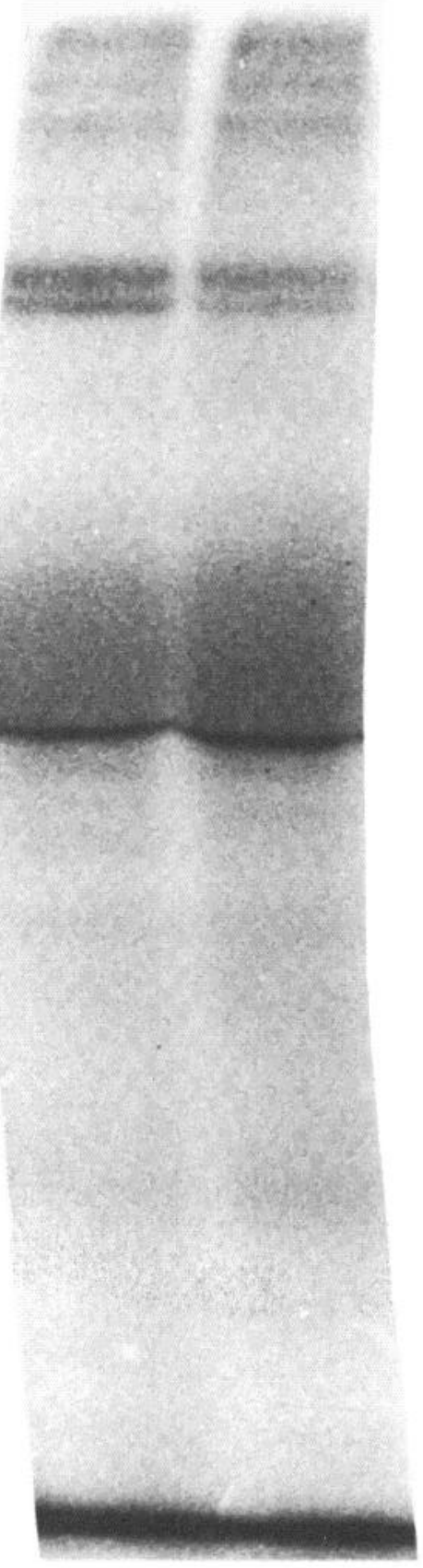

left right

\section{Denervated Ganglia}

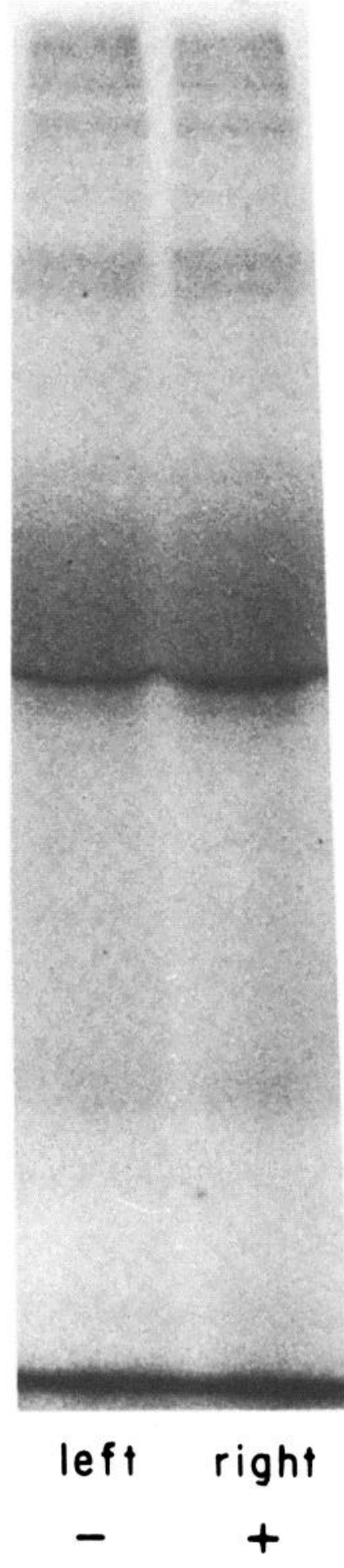

Figure 4. Autoradiograph showing the effect of dopamine on the state of phosphorylation of Protein I in superior cervical ganglia of intact or bilaterally denervated rabbits. The right intact or right denervated ganglion of a rabbit was incubated in standard Locke's buffer containing $100 \mu \mathrm{M}$ dopamine for $4 \mathrm{~min}$. The left intact or denervated control ganglia were incubated in standard Locke's buffer. The ganglia then were homogenized in 1\% SDS. The Protein I contained in the SDS extracts was immunoprecipitated, back phosphorylated, and subjected to SDS-polyacrylamide gel electrophoresis. 


\section{Intact Ganglia}

\section{Denervated Ganglia}
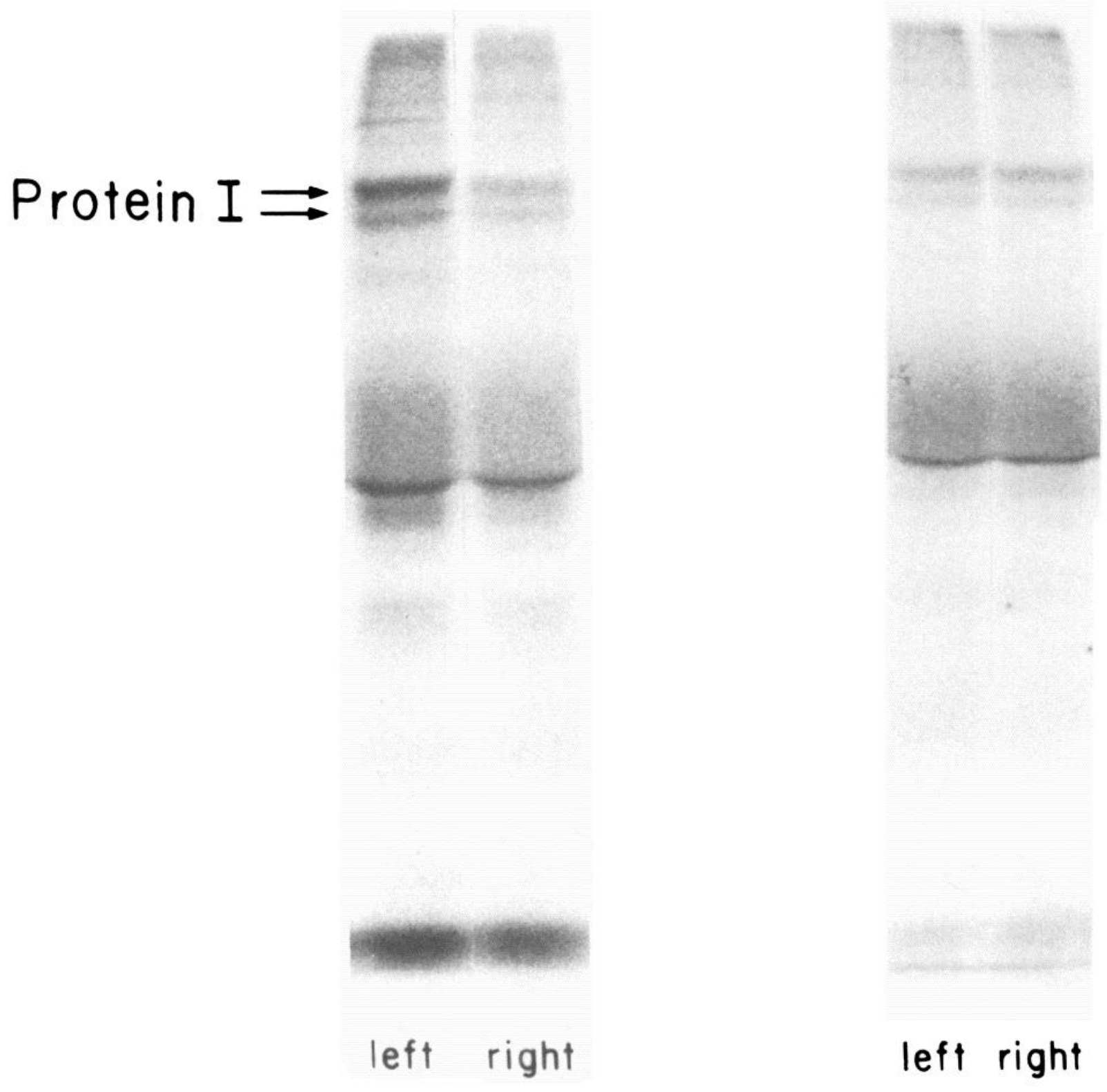

\section{High $\mathrm{K}^{+}$}

Figure 5. Autoradiograph showing the effect of a high $\mathrm{K}^{+}$concentration on the state of phosphorylation of Protein I in superior cervical ganglia of intact or bilaterally denervated rabbits. The right intact or right denervated ganglion of a rabbit was incubated in modified Locke's buffer containing $60 \mathrm{~mm} \mathrm{~K}^{+}$for $1 \mathrm{~min}$. The left intact or denervated control ganglia were incubated in standard Locke's buffer. The ganglia then were homogenized in $1 \%$ SDS. The Protein I contained in the SDS extracts was immunoprecipitated, back phosphorylated, and subjected to SDS-polyacrylamide gel electrophoresis.

is destroyed by denervation but unaffected by short exposure to cycloheximide and a postsynaptic pool that is unaffected by denervation but decreased by short exposure to cycloheximide. In support of this interpretation, short exposure to cycloheximide failed to alter the Protein I content of the adrenal medulla, a tissue in which Protein I is primarily, and possibly exclusively, presynaptic (Fried et al., 1982). These observations are consistent with the idea that the Protein I contained in the cell bodies of ganglionic neurons is newly synthesized and en route to the nerve terminals arising from the cell bodies. That cycloheximide failed to reduce Protein I 
TABLE IV

Regulation of the state of phosphorylation of Protein I in rabbit superior cervical ganglia: Analysis of phosphorylation sites

Rabbit superior cervical ganglia were treated as described in the legend to Table III, Column A. The ${ }^{32} \mathrm{P}$-labeled holo-Protein I bands obtained from those experiments were subjected to one-dimensional peptide-mapping analysis. The ${ }^{32} \mathrm{P}$ contained in the $M_{\mathrm{r}}=10,000$ and $M_{\mathrm{r}}$ $=34,000$ phosphopeptide fragments of Protein I from test ganglion and contralateral control ganglion was quantitated. The amount of dephosphopeptide fragment in test ganglion was compared to that in its contralateral control ganglion. Data are expressed as the mean \pm SEM. The numbers in parentheses represent the number of pairs of ganglia.

\begin{tabular}{|c|c|c|}
\hline \multirow[b]{2}{*}{ Condition } & \multicolumn{2}{|c|}{ Dephospho-Protein I } \\
\hline & $\begin{array}{c}M_{\mathrm{r}}=10,000 \\
\text { Fragment }\end{array}$ & $\begin{array}{c}M_{\mathrm{r}}=34,000 \\
\text { Fragment }\end{array}$ \\
\hline & \multicolumn{2}{|c|}{$\%$ contralateral control } \\
\hline a. Control & $102 \pm 4$ & $96 \pm 6$ \\
\hline $\begin{array}{l}\text { b. Preganglionic nerve stimula- } \\
\text { tion }\end{array}$ & $53 \pm 7^{a}$ & $57 \pm 4^{a}$ \\
\hline c. Dopamine & $68 \pm 3^{a}(10)$ & $80 \pm 6(10)$ \\
\hline d. High $\mathrm{K}^{+}$concentration & $57 \pm 4^{a}$ & $50 \pm 6^{a}$ \\
\hline $\begin{array}{l}\text { e. Postganglionic nerve stimula- } \\
\text { tion }\end{array}$ & $105 \pm 8$ & $103 \pm 7$ \\
\hline $\begin{array}{l}\text { f. Dopamine } \\
\text { amine }\end{array}$ & $105 \pm 3$ & $105 \pm 7$ \\
\hline $\begin{array}{l}\text { g. Preganglionic nerve stimula- } \\
\text { tion }+ \text { phenoxybenzamine, } \\
\text { hexamethonium, and atro- } \\
\text { pine }\end{array}$ & $64 \pm 6^{a}$ & $69 \pm 4^{a}$ \\
\hline h. 8-Bromo-cyclic AMP & $52 \pm 6^{a}$ & $115 \pm 26$ \\
\hline i. Forscolin & $43 \pm 9^{a}$ & $122 \pm 43$ \\
\hline
\end{tabular}

${ }^{a}$ Significantly different from control $(p<0.05)$ by two-tailed $t$ test.

levels in denervated ganglia to zero may be explained by the observation (see "Materials and Methods") that cycloheximide only partially inhibited in vivo protein synthesis.

The development of the procedure described here for quantitating the state of phosphorylation of Protein $I$ in SDS extracts of nervous tissue has allowed us to study the regulation of Protein I phosphorylation in the rabbit superior cervical ganglion. The results of this study demonstrate that impulse conduction, at a physiological frequency (Douglas and Ritchie, 1957), increased the phosphorylation of Protein $I$ in the rabbit ganglion. In a related study (Nestler and Greengard, 1982), we have shown that as few as 20 nerve impulses caused a halfmaximal increase in Protein I phosphorylation and that as few as 50 nerve impulses maximally increased Protein I phosphorylation in the rabbit ganglion. In addition to nerve impulse conduction, dopamine and a high $\mathrm{K}^{+}$concentration also were found to increase Protein I phosphorylation in the rabbit superior cervical ganglion as had been observed in bovine ganglion sections (Nestler and Greengard, 1980).

The changes observed in Protein I phosphorylation in response to impulse conduction, to dopamine, and to a high $\mathrm{K}^{\prime}$ concentration appeared to occur in the presynaptic nerve terminals that innervate the ganglion. Thus, in contrast to the situation with intact rabbit ganglia, in which dopamine and a high $\mathrm{K}^{+}$concentration increased Protein I phosphorylation, dopamine and a high $\mathrm{K}^{+}$ concentration did not increase Protein I phosphorylation in denervated rabbit ganglia. Similarly, whereas stimu- lation of preganglionic nerves (orthodromic impulse conduction) increased Protein I phosphorylation in intact rabbit ganglia, stimulation of postganglionic nerves (antidromic impulse conduction) did not increase Protein I phosphorylation in intact rabbit ganglia. Finally, the increase in the state of phosphorylation of Protein I elicited by preganglionic nerve stimulation was not blocked by neurotransmitter antagonists that abolish the three known postsynaptic potentials observed in rabbit ganglia. These latter results not only indicate that the effect of impulse conduction on Protein I phosphorylation occurs on Protein I located in presynaptic nerve terminals but also suggest that the effect is a direct one, not secondary to released endogenous neurotransmitter acting on presynaptic nerve terminals.

Most of the Protein I present in control ganglia was in the dephosphorylated form (see "Materials and Methods"). The maximal decrease observed in dephosphoProtein I in intact ganglia, as a result of its phosphorylation by various stimuli, was about $50 \%$. Since this decrease apparently occurred in presynaptic nerve terminals, which contain only $60 \%$ of the total ganglion Protein I, stimulation of ganglia appears to have resulted in the conversion of more than $80 \%$ of the presynaptic Protein I from the dephosphorylated to the phosphorylated form. The reason for the inability of dopamine and of a high $\mathrm{K}^{+}$concentration to stimulate the phosphorylation of postsynaptic Protein I in rabbit ganglia remains unknown but raises the possibility that postsynaptic Protein $I$ is not accessible to endogenous protein kinases.

The effects of nerve impulse conduction and of a high $\mathrm{K}^{+}$concentration were dependent on extracellular calcium, but those of dopamine and of 8-bromo-cyclic AMP were not. Similar results were obtained in experiments on bovine superior cervical ganglion sections (Nestler and Greengard, 1980). The findings are consistent with the view that impulse conduction and a high $\mathrm{K}^{+}$concentration increase Protein I phosphorylation through the activation of calcium-dependent protein kinases and that dopamine and 8-bromo-cyclic AMP increase Protein I phosphorylation through the activation of cyclic AMP. dependent protein kinase. Activation of calcium-dependent protein kinases would be expected to increase the state of phosphorylation of Protein I both in the collagenase-insensitive and in the collagenase-sensitive regions of the molecule. In contrast, activation of cyclic AMP-dependent protein kinase would be expected to increase the state of phosphorylation of Protein I only in the collagenase-insensitive region of the molecule. Consistent with this interpretation are the observations that nerve impulse conduction and a high $\mathrm{K}^{+}$concentration stimulated the phosphorylation of both regions of Protein I and that dopamine, 8-bromo-cyclic AMP, and forscolin (an activator of adenylate cyclase) stimulated the phosphorylation only of the collagenase-insensitive region of the molecule.

The conclusions based on the present studies of the rabbit superior cervical ganglion are summarized in Figure 6. The state of phosphorylation of presynaptic Protein I was regulated by impulse conduction, by dopamine, and by a high $\mathrm{K}^{+}$concentration, whereas the total amount of presynaptic Protein I was not decreased by short periods of exposure to cycloheximide, a protein 
THE RABBIT SUPERIOR CERVICAL GANGLION CONTAINS TWO POOLS OF PROTEIN I, ONE PRESYNAPTIC AND ONE POSTSYNAPTIC, WITH DIFFERENT CHARACTERISTICS

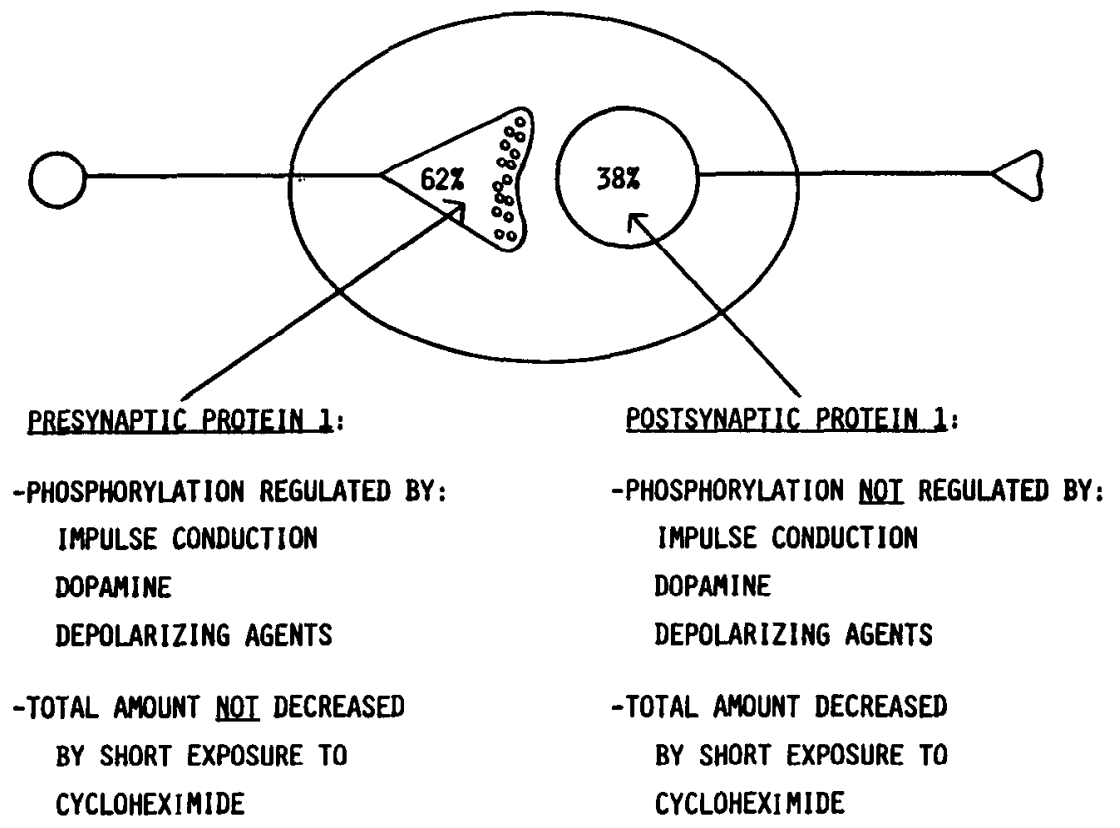

Figure 6. Schematic representation of the distribution and regulation of Protein I in the rabbit superior cervical ganglion. See the text for discussion.

synthesis inhibitor. In contrast to presynaptic Protein I, the state of phosphorylation of postsynaptic Protein I was not regulated by impulse conduction, by dopamine, or by a high $\mathrm{K}^{+}$concentration, whereas the total amount of postsynaptic Protein I was decreased by short periods of exposure to cycloheximide. These results are consistent with the scheme that the Protein I located in presynaptic nerve terminals plays a functional role and that the Protein I located in cell bodies is newly synthesized and is en route to nerve terminals.

Protein I appears to be present at a high concentration in most, and possibly in all, neurons (P. De Camilli, W. B. Huttner, M. Harris, R. Cameron, and P. Greengard, manuscript in preparation), suggesting that it plays an essential role in neuronal function. Furthermore, Protein I appears to be concentrated in most, and possibly all, presynaptic nerve terminals (De Camilli et al., 1980; $\mathrm{P}$. De Camilli, W. B. Huttner, M. Harris, R. Cameron, and $P$. Greengard, manuscript in preparation), suggesting that it plays an essential role in synaptic function. The apparent localization of Protein I to neurotransmitter vesicles (Bloom et al., 1979; Ueda et al., 1979; P. De Camilli, W. B. Huttner, M. Harris, R. Cameron, and P. Greengard, manuscript in preparation) suggests that Protein $I$ is involved in some aspect of the functioning of those vesicles, such as neurotransmitter release. In contrast to the ubiquity of Protein $I$ in nervous tissue, Protein $I$ is virtually absent from non-nervous tissue, including even those tissues with a secretory function (De Camilli et al., 1979; Fried et al., 1982; P. De Camilli, W. B. Huttner, M. Harris, R. Cameron, and P. Greengard, manuscript in preparation). These findings suggest that Protein I may play a role in a neuron-specific regulation of the release process rather than in the release process per se. It is interesting to note in this regard that cyclic
AMP and calcium, both of which have been shown to regulate Protein I phosphorylation in various neuronal preparations, also have been found to facilitate neurotransmitter release at a variety of synapses (Miyamoto and Breckenridge, 1974; Kupfermann, 1980; Rosenthal, 1969; Erulkar and Rahamimoff, 1978). For example, catecholamines, including dopamine, apparently acting through cyclic AMP, produce a long lasting facilitation of acetylcholine release in vertebrate sympathetic ganglia (Kuba et al., 1981). Similarly, brief periods of impulse conduction, apparently acting through calcium, produce a long lasting facilitation of acetylcholine release in the rabbit superior cervical ganglion, a process referred to as post-tetanic potentiation (Zengel et al., 1980). It is possible, therefore, that an increase in the state of phosphorylation of Protein I represents a common molecular pathway through which certain neurotransmitters and brief periods of impulse conduction facilitate neurotransmitter release.

\section{References}

Adair, W. S., D. Jurivich, and U. W. Goodenough (1978) Localization of cellular antigens in sodium dodecyl sulfate-polyacrylamide gels. J. Cell Biol. 79: 281-285.

Bloom, F. E., T. Ueda, E. Battenberg, and P. Greengard (1979) Immunocytochemical localization in synapses of Protein $I$, an endogenous substrate for protein kinases in mammalian brain. Proc. Natl. Acad. Sci. U. S. A. 76: 5982-5986.

Campbell, D. H., J. S. Garvey, N. E. Cremer, and D. H. Sussdorf (1970) Methods in Immunolngy, Ed. 2, W. A. Benjamin, New York.

Cleveland, D. W., S. G. Fischer, M. W. Kirschner, and U. K. Laemmli (1977) Peptide mapping by limited proteolysis in sodium dodecyl sulfate and analysis by gel electrophoresis. J. Biol. Chem. 252: 1102-1106.

De Camilli, P., T. Ueda, F. E. Bloom, E. Battenberg, and P. Greengard (1979) Widespread distribution of Protein I in the 
central and peripheral nervous system. Proc. Natl. Acad. Sci. U. S. A. 76: 5977-5981.

De Camilli, P., R. Cameron, and P. Greengard (1980) Localization of Protein I by immunofluorescence in the adult and developing nervous system. J. Cell Biol. 87: 72a.

Dolphin, A. C., and P. Greengard (1981a) Serotonin stimulates the phosphorylation of Protein I, a synapse-specific protein in the facial motor nucleus of rat brain. Nature 289: 76-79.

Dolphin, A. C., and P. Greengard (1981b) Neurotransmitterand neuromodulator-dependent alterations in phosphorylation of Protein I in slices of rat facial nucleus. J. Neurosci. 1: 192-203.

Douglas, W. W., and J. M. Ritchie (1957) A technique for recording functional activity in specific groups of medullated and non-medullated fibres in whole nerve trunks. J. Physiol. (Lond.) 138: 19-30.

Dun, N., and S. Nishi (1974) Effects of dopamine on the superior cervical ganglion of the rabbit. J. Physiol. (Lond.) 239: 155-164.

Erulkar, S. D., and R. Rahamimoff (1978) The role of calcium ions in tetanic and post-tetanic increase of miniature endplate potential frequency. J. Physiol. (Lond.) 287: 501-511.

Forn, J., and P. Greengard (1978) Depolarizing agents and cyclic nucleotides regulate the phosphorylation of specific neuronal proteins in rat cerebral cortex slices. Proc. Natl. Acad. Sci. U. S. A. 75: 5195-5199.

Fried, G., E. J. Nestler, P. De Camilli, L. Stjarne, L. Olson, J. M. Lundberg, T. Hokfelt, C. C. Ouimet, and P. Greengard (1982) Cellular and subcellular localization of Protein I in the peripheral nervous system. Proc. Natl. Acad. Sci. U. S. A. 79: 2717-2721.

Glynn, I. M., and J. B. Chapell (1964) A simple method for the preparation of ${ }^{32} \mathrm{P}$-labeled adenosine triphosphate of high specific activity. Biochem. J. 90: 147-149.

Goelz, S. E., E. J. Nestler, B. Chehrazi, and P. Greengard (1981) Distribution of Protein I in mammalian brain as determined by a detergent-based radioimmunoassay. Proc. Natl. Acad. Sci. U. S. A. 78: 2130-2134.

Greengard, P. (1978) Phosphorylated proteins as physiological effectors. Science 199: 146-152.

Greengard, P. (1982) Intracellular signals in the brain. Harvey Lect. 75:277-331.

Huttner, W. B., and P. Greengard (1979) Multiple phosphorylation sites in Protein $\mathrm{I}$ and their differential regulation by cyclic AMP and calcium. Proc. Natl. Acad. Sci. U. S. A. 76: 5402-5406.

Huttner, W. B., L. J. DeGennaro, and P. Greengard (1981) Differential phosphorylation of multiple sites in purified Protein I by cyclic AMP-dependent and calcium-dependent protein kinases. J. Biol. Chem. 256: 1482-1488.

Kalix, P., D. A. McAfee, M. Schorderet, and P. Greengard (1974) Pharmacological analysis of synaptically mediated increase in cyclic adenosine monophosphate in rabbit superior cervical ganglion. J. Pharmacol. Exp. Ther. 188: 676-687.

Kennedy, M. B., and P. Greengard (1981) Two calcium/calmodulin-dependent protein kinases, which are highly concentrated in brain, phosphorylate Protein I at distinct sites. Proc. Natl. Acad. Sci. U. S. A. 78: 1293-1297.

Kosterlitz, H. W., and D. I. Wallis (1966) The effects of hexamethonium and morphine on transmission in the superior cervical ganglion of the rabbit. $\mathrm{Br}$. J. Pharmacol. Chemother. 26: 334-344.

Krueger, B. K., J. Forn, and P. Greengard (1977) Depolarization-induced phosphorylation of specific proteins, mediated by calcium ion influx, in rat brain synaptosomes. J. Biol. Chem. 252: 2764-2773.

Kuba, K., E. Kato, E. Kumamoto, K. Koketsu, and K. Hirai (1981) Sustained potentiation of transmitter release by adrenaline and dibutyryl cyclic AMP in sympathetic ganglia. $\mathrm{Na}$ ture 291: 654-656.
Kupfermann, I. (1980) Role of cyclic nucleotides in excitable cells. Annu. Rev. Physiol. 42: 629-641.

Libet, B. (1970) Generation of slow inhibitory and excitatory post-synaptic potentials. Fed. Proc. 29: 1945-1956.

McAfee, D. A., B. K. Henon, G. J. Whiting, J. P. Horn, P. J. Yarowsky, and D. K. Turner (1980) The action of cAMP and catecholamines in mammalian sympathetic ganglia. Fed. Proc. 39: 2997-3002.

Miyamoto, M. D., and B. M. Breckenridge (1974) A cyclic adenosine monophosphate link in the catecholamine enhancement of transmitter release at the neuromuscular junction. J. Gen. Physiol. 63: 609-624.

Nestler, E. J., and P. Greengard (1980) Dopamine and depolarizing agents regulate the state of phosphorylation of Protein I in the mammalian superior cervical sympathetic ganglion. Proc. Natl. Acad. Sci. U. S. A. 77: 7479-7483.

Nestler, E. J., and P. Greengard (1982) Nerve impulses increase the phosphorylation state of Protein $I$ in rabbit superior cervical ganglion. Nature 296: 452-454.

Nja, A., and D. Purves (1978) Specificity of initial synaptic contacts made on guinea-pig superior cervical ganglion cells during regeneration of the cervical sympathetic trunk. J. Physiol. (Lond.) 281: 45-62.

Ostberg, A. J. C., G. Raisman, P. M. Field, L. L. Iversen, and R. E. Zigmond (1976) A quantitative comparison of the formation of synapses in the rat superior cervical sympathetic ganglion by its own and foreign nerve fibers. Brain Res. 107: 445-470.

Parkhouse, R. M. E., B. A. Askonas, and R. R. Dourmashkin (1970) Electron microscopic studies of mouse immunoglobulin $\mathrm{M}$; structure and reconstitution following reduction. Immunology 18: 575-584.

Rainbow, T. C., P. L. Hoffman, and L. B. Flexner (1980a) Studies of memory: A reevaluation in mice of the effects of inhibitors on the rate of synthesis of cerebral proteins as related to amnesia. Pharmacol. Biochem. Behav. 12: 79-84.

Rainbow, T. C., P. G. Davis, and B. S. McEwen (1980b) Anisomycin inhibits the activation of sexual behavior by estradiol and progesterone. Brain Res. 194: 548-555.

Raine, A. E. G., and I. W. Chubb (1977) Long term $\beta$-adrenergic blockade reduces tyrosine hydroxylase and dopamine $\beta$-hydroxylase activities in sympathetic ganglia. Nature 267: 265-267.

Rosenthal, J. (1969) Post-tetanic potentiation at the neuromuscular junction of the frog. J. Physiol. (Lond.) 203: 121-133.

Seamon, K. B., W. Padgett, and J. W. Daly (1981) Forskolin: Unique diterpine activator of adenylate cyclase in membranes and in intact cells. Proc. Natl. Acad. Sci. U. S. A. 78: 3363-3367.

Ueda, T., and P. Greengard (1977) Adenosine 3':5'-monophosphate-regulated phosphoprotein system of neuronal membranes. I. Solubilization, purification, and some properties of an endogenous phosphoprotein. J. Biol. Chem. 252: 5155-5163.

Ueda, T., P. Greengard, K. Berzins, R. S. Cohen, F. Blomberg, D. J. Grab, and P. Siekevitz (1979) Subcellular distribution in cerebral cortex of two proteins phosphorylated by a cAMP. dependent protein kinase. J. Cell Biol. 83: 308-319.

Walter, P., and G. Blobel (1980) Purification of a membraneassociated protein complex required for protein translocation across the endoplasmic reticulum. Proc. Natl. Acad. Sci. U. S. A. 77: 7112-7116.

Yu, F. -L., and P. Feigelson (1972) The rapid turnover of RNA polymerase of rat liver nucleolus, and of its messenger RNA. Proc. Natl. Acad. Sci. U. S. A. 69: 2833-2837.

Zengel, J. E., K. L. Magleby, J. P. Horn, D. A. McAfee, and P. J. Yarowsky (1980) Facilitation, augmentation, and potentiation of synaptic transmission at the superior cervical ganglion of the rabbit. J. Gen. Physiol. 76: 213-231. 